This is the ninth award of the Forestry Memorial scholarship. It was established by alumni and friends of the faculty in memory of graduates and undergraduates who have lost their lives in war or in civilian pursuits. It is awarded on the basis of standing in the Ontario Grade XIII examinations.

The Schlich Memorial Fund Award, which was made available to the Faculty of Forestry in the University of Toronto for the session 1949-50, has been awarded to J. L. Ladell, an ex-service student, who obtained the highest mark in Silvics at the annual examinations in third year in April.

\title{
GRADUATE LOGGING CHAIR
}

An extension of facilities in the Maritimes only forestry school was announced recently by Dr. A. W. Trueman, president of the University of New Brunswick. Dr. Trueman announced the establishment of a graduate chair of logging, financially supported by four Eastern Canadian paper com panies, as part of the U.N.B. forestry faculty. The new department will begin operations with the opening of the fall term later this month.

The four companies have underwritten the chair for a period of five years, believing that more specialized training in logging is needed in the Canadian forest industries. Included in the agreement with the university are the Canadian International Paper Company, the Quebec-North Shore Paper Company, Ltd., the Fraser Companies, Ltd., and the Bathurst Power and Paper Company, Ltd.

The new department will be the first exclusively graduate department to be set up at the University of New Brunswick, with courses to be offered only to graduate foresters who plan to specialize in logging. Students will enter upon a one-year program leading to the degree of Master of Science in Forestry. Similar degrees have been available for some time in other forestry subjects. Plans for the curriculum to be followed include experimental logging on the university's 7,000-acre forest property and visits to commercial logging operations in the field.

Further details of the curriculum and staff of the new chair will be announced at a later date, Dr. Trueman said.

\section{FARM WOODLOTS IN THE UNITED STATES ${ }^{1}$}

According to estimates made by the Forest Service, there are some 261 million acres of woodland in the United States holdings of less than 5,000 acres. This acreage is held by 4 million private owners, about half of whom are farmers.

Although the economic benefits of farm forestry were advocated by foresters in the United States more than a half-century ago, little was done to promote forestry on small holdings until the 1920's when some of the state nurseries began producing nursery-grown trees for farm planting. With the passage of the Clarke-McNary Act in 1924 a national policy of government assistance to farm woodland owners was adopted. This act authorized a federal-state cooperative extension program of technical forest-management assistance to farmers.

1 Discussion by Henry Clepper, Executive Secretary, Society of American Foreters, program topic "Farm Woodlota"" at the annual meeting of the Canadian Society of Forest Engineers, Sault Ste. Marie, Ontario, October 27, 1950. 
This program was further strengthened in 1937 with the enactment of the Norris-Doxey Cooperative Farm Forestry Act. Through the stimulus of this law, there are now 225 farm woodland management projects, covering 994 counties, in 38 states, under the general supervision of the state forestry agencies. In addition to these projects, educational and demonstration work in farm forestry is carried on by state extension services in 45 states employing 68 extension foresters.

But this is not all. In hundreds of soil conservation districts, professional foresters employed by the Soil Conservation Service of the U.S. Department of Agriculture are available to assist owners of small timber properties. A dozen farm forestry cooperatives also provide management and marketing assistance to owners of small holdings. Finally, the industrysponsored tree farm system is supplying educational and publicity material to landowners who are increasingly requesting the assistance of the state forestry agencies in providing more information about forest protection and tree growing.

Despite the gains made in rendering assistance to owners of small woodlands during the past decade, the bulk of these lands are not being managed for continuous forest production. Although some 250 full-time consulting foresters are available to provide management advice and service to private owners, in addition to the publicly employed farm foresters and extension foresters, the need for stepping up this management-assistance program is recognized as one of the still unsolved forestry problems.

\section{EDITOR'S NOTE}

The following items were omitted in the article, "Some Historical Aspects of Forestry in Ontario", by A. P. Leslie, which appeared in "The Forestry Chronicle", Volume 26, No. 3, September, 1950, p. 243-250:

1924 Forest trees nursery started by J. F. Turnbull, Department of Lands and Forests, North Bay. This was continued until about 1934 and some denuded timberland was planted.

1948 Forest tree nursery started on Manitoulin Island by the Ontario Paper Company.

1949-50 should be the date for publication in the Woodland Review of articles on silvicultural research by the member companies.

\section{NEW BOOKS}

"The Establishment of Vegetation on Industrial Waste Land", R. O. Whyte and J. W. B. Sisam, published by the Commonwealth Bureau of Pastures and Field Crops, Aberstwyth, Wales.

"Porest Management", by Herbert H. Chapman, M.F., Sc.D., published by the Hildreth Press, Bristol, Conn. 